\title{
Economic return on investments in research and development (R\&D) in Pinus and Eucalyptus plantations in Brazil
}

\author{
Vinicius Evangelista Silva $\mathbb{1}^{1 *}$ José Geraldo Mageste ${ }^{2}$ João Paulo Guimarães Vieira ${ }^{1}$ Otávio Augusto \\ Tessarollo Ribeiro ${ }^{3}$ Vanessa Janni Epelbaum ${ }^{1}$
}

${ }^{1}$ Consultec - Soluções em Tecnologia Florestal, Brasil

${ }^{2}$ Universidade Federal de Uberlândia, Rodovia LMG 746, Km 01, s/nº, CEP: 38.500-000, Monte Carmelo - MG, Brasil

${ }^{3}$ Vimef - Soluções Florestais., : R. Juca Prates, 1014, Centro, CEP: 39400-078, Montes Claros - MG, Brasil

${ }^{4}$ Fundação Getulio Vargas, Rua da Candelária, 6 Centro, 20091-020, Rio de Janeiro, RJ, Brasil

\section{Original Article \\ *Corresponding author: viniciusesilva@yahoo.com.b $\mathrm{r}$ \\ Keywords: \\ Planted forests, \\ Economic return rates, \\ Wood productivity,}

Forestry technology

Palavras-chave:

Florestas plantadas,

Índices de retorno econômico,

Produtividade de madeira,

Tecnologia florestal.

Received in

2020/08/19

Accepted on

2021/06/28

Published in

2020/08/31

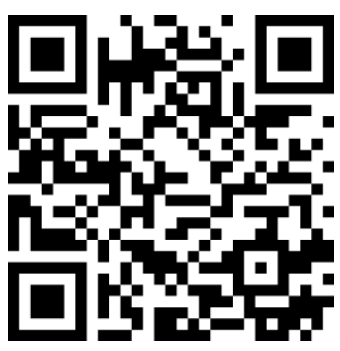

DOI: http://dx.doi.org/ 10.34062/afs.v8i2.10998

\section{(cc) BY}

ABSTRACT: Currently, public and private resources are directed towards the development of Research and Development (R\&D) projects in the Brazilian forestry area. But, many times, such investments are used only as corporate advertising, without the knowledge of their real return, underestimating the importance of R\&D in the development of organizations in this sector. Hence the importance of studies that seek to evaluate investment returns and how profitable they are for society and for technological innovation. The objective of this study was to evaluate the possible economic return of $R \& D$ in the Brazilian Forest Sector, in particular, its effects on increasing the productivity of Pinus and Eucalyptus stands. Through the publications of the Statistical Yearbook of the Brazilian Association of Planted Forest Producers (ABRAF) it was possible to understand the relationship between investments in R\&D, planted area and annual current wood productivity, using an indicator that related Investments and Revenue in the R\&D of organizations Brazilian forestry companies of this Association. It can be inferred that for every $\mathrm{R} \$ 1.00$ invested in $\mathrm{R} \& \mathrm{D}$ projects, an average return of $\mathrm{R} \$ 15.02$ is obtained in such organizations. It was also concluded that the marginal gains in annual wood productivity correlated positively and significantly with investments in $R \& D(r=0.43)$. Thus, investments in $R \& D$ made by silvicultural organizations translate into an economic return for them, as well as that their absence can stagnate the increase in wood productivity.

\section{Retorno econômico dos investimentos em pesquisa e desenvolvimento (P\&D) em plantações de Pinus e Eucalyptus no Brasil}

RESUMO: Atualmente, são direcionados recursos públicos e privados para desenvolvimento de projetos de Pesquisa e Desenvolvimento (P\&D) na área de silvicultura brasileira. Mas, muitas vezes, tais investimentos são utilizados apenas como propaganda corporativa, sem o conhecimento do seu real retorno, subvalorizando-se a importância da P\&D no desenvolvimento das organizações deste setor. Daí a importância de estudos que procurem avaliar os retornos dos investimentos e o quanto são proveitosos para a sociedade e para inovação tecnológica. O objetivo deste estudo foi avaliar o possível retorno econômico da P\&D no Setor Florestal Brasileiro, em especial, seus efeitos no aumento da produtividade dos povoamentos de Pinus e eucalipto. Através das publicações do Anuário Estatístico da Associação Brasileira de Produtores de Florestas Plantadas (ABRAF) foi possível entender a relação entre investimentos em $\mathrm{P} \& \mathrm{D}$, área plantada e produtividade de madeira corrente anual, usando-se um indicador que relacionou Investimentos e Receitas na P\&D das organizações florestais brasileiras desta Associação. Pode-se inferir que a cada $\mathrm{R} \$ 1,00$ investido em projetos de $\mathrm{P} \& \mathrm{D}$, obtém-se um retorno médio de $\mathrm{R} \$ 15,02$ em tais organizações. Também se concluiu que os ganhos marginais de produtividade (anuais) de madeira correlacionaram-se positivamente e significativamente com os investimentos em $\mathrm{P} \& \mathrm{D}(\mathrm{r}=0,43)$. Assim, os investimentos em $\mathrm{P} \& \mathrm{D}$ realizados pelas organizações silviculturais se traduzem em retorno econômico para as mesmas, bem como que a ausência deles pode estagnar o aumento da produtividade de madeira. 


\section{Introduction}

Lee (2020) begins his works by warning that productivity is not equivalent to product or production. According to this author, productivity reflects improvements in the ability to transform inputs into products. In the most literal sense, it is a residual measure of the contribution to product growth after all factors have been considered. It is the non-physical product of innovation, efficiency, management, research, climate and luck. In this way, the economic development of companies is directly related to their intellectual capital, with intellectual capital being the name given to all information, transformed into knowledge that adds to those that you already have.

According to Wen (1993) and Garcia-Marin and Voigtländer (2019), there are three factors that drive productivity: increase in the quantity of inputs, institutional innovation, and the third source of growth is technological progress, which shifts the production function upwards. Technological progress is generally embedded in improving human quality and physical capital. Therefore, with the same number of inputs, more product becomes available.

Many public and private resources are directed towards the development of Research and Development (R\&D) activities, but they are often used only as corporate advertising, and, thus, the importance of R\&D in the development of Brazilian Forestry companies is underestimated.

Especially at the time of the great financial and economic crises that afflict companies, the resources directed to $\mathrm{R} \& \mathrm{D}$ activities are reduced, as they are treated as investments in the financial structure of companies, and not as direct inputs of production. With that, several research are interrupted and the field of knowledge goes through a regressive state.

Consequently, it is essential to carry out studies that seek to evaluate the returns on investments in research and to determine how profitable these have been proving to society. A limited number of studies are found in the literature aiming to measure the economic returns from investments in Research and Development - R\&D in different productive sectors. Especially, in the case of agriculture, there are many studies of this nature, such as Huffman and Evenson (1993), Alston et al. (1998), Ruttan (1982), Fuglie et al. (1996) and Yee et al. (2002), who evaluated the returns to $R \& D$ in North American agriculture; Rosegrant and Evenson (1992), who assessed the returns to $R \& D$ in agriculture in South Asia; Gasques et al. (2000), who evaluated the returns of R\&D in Brazilian agriculture; Araújo et al. (2002), who evaluated the returns to $R \& D$ in agriculture in São Paulo, Figueiredo et al. (2012) reduced the R\&D gains in the São Paulo citrus industry in observed, significantly increasing the leverage of $R \& D$ in citrus culture.

Brazil has a wide vocation in the forestry area and is currently one of the most competitive countries in terms of productivity and cost of wood, largely due to the high level of forestry and industrial technology, provided by $R \& D$ activities (ABRAF, 2013).

In this context, the objective of this work was to evaluate the economic return of investments in Research and Development (R\&D) in the Brazilian Forest Sector, in particular, it's effects in increasing the productivity of Pinus and Eucalyptus forests, and indirectly in reducing wood costs.

\section{Material and Methods}

Research data source

Publications from the Brazilian Association of Planted Forest Producers (ABRAF) between 2007 and 2014 were the base of dates for development this manuscript (ABRAF, 2007, 2008, 2009, 2010, 2011, 2012, 2013, 2014). To prepare the yearbook, ABRAF adopted methodological procedures for comparing data, estimates, crossing data, etc.

The quantitative analysis presented in the Yearbooks derived from the collection of primary and secondary data. Primary data were obtained through:

- Completion of complete questionnaires by ABRAF member companies;

- Completion of simplified questionnaires by state collective associations associated with ABRAF;

- Contact with class associations such as ABIPA (Brazilian Association of the Wood Panel Industry), BRACELPA (Brazilian Association of Pulp and Paper), ABIMÓVEL (Brazilian Association of Furniture Industries) and SINDIFER - MG (Union of the Iron Industry of the State Minas Gerais) and others;

- Direct research, with the collection of information from non-ABRAF companies.

Secondary data were collected from research institutions such as the Brazilian Institute of Geography and Statistics (IBGE), the National Bank for Economic and Social Development (BNDES), the Institute of Agricultural Economics of São Paulo, the Association of Rubber Producers and Beneficiaries of São Paulo (APABOR), Paricá Research Center, official data platform such as Alice Web, from the Ministry of Industry, Foreign Trade and Services (MDIC), General Registry of Employed and Unemployed (CAGED) from the Ministry of Labor and Employment (MTE), Ministry of the Environment (MMA) and Ministry of Agrarian Development (MDA).

Information on planted areas in Brazil was presented by state of the Federation, and the 
methodology for obtaining these estimates was detailed below, for each state:

- Amapá: the planted area was estimated from direct contact with forestry companies not associated with ABRAF. It is estimated that the margin of error can vary by $22.5 \%$ more or less.

- Goiás: the planted area was estimated from direct contact with forestry companies not associated with ABRAF and through the mapping of forestry plantations using Landsat - 5 satellite images (2011/2012), with a spatial resolution of 30 meters. It is estimated that the margin of error can vary by $20 \%$ more or less.

- Bahia: the planted area was estimated based on information made available by individual members to ABRAF and by direct contact with forestry companies not associated with ABRAF. It is estimated that the margin of error may vary by $7.4 \%$ more or less.

- Espírito Santo: the planted area was estimated based on the information provided by ABRAF's individual associates and by direct contact with forestry companies not associated with ABRAF. It is estimated that the margin of error may vary by $14.3 \%$ more or less.

- Maranhão: the planted area was estimated based on the information made available by ABRAF individual members and by direct contact with forestry companies not associated with ABRAF. It is estimated that the margin of error can vary by $12.2 \%$ more or less.

- Pará: the planted area was estimated based on the information provided by ABRAF's individual associates and by direct contact with forestry companies not associated with ABRAF. It is estimated that the margin of error can vary by $26.6 \%$ more or less.

- Mato Grosso: the planted area was estimated based on information made available by individual and collective associates to ABRAF, as well as by direct contact with non-associated forestry companies. It is estimated that the margin of error can vary by $16.4 \%$ more or less.

- Mato Grosso do Sul: the planted area was estimated based on information provided by ABRAF individual members, REFLORE and direct contact with forestry companies not associated with ABRAF. It is estimated that the margin of error can vary by $3.3 \%$ more or less.

- Minas Gerais: the Eucalyptus planted area was estimated based on the information provided by AMS in view of the information obtained by individual ABRAF members and by direct contact with companies not associated with ABRAF. The planted area of Pinus was estimated based on the information made available by individual associates to ABRAF and by direct contact with non-associated forestry companies. It is estimated that the margin of error may vary by $2.1 \%$ more or less.
- Paraná: the planted area was estimated based on information made available by individual members to ABRAF, by the Paranaense Association of Forest Based Companies (APRE), by the Association of Leaf Smoke Planters in Rio Grande do Sul (AFUBRA), and by direct contact with forestry companies not associated with ABRAF. It is estimated that the margin of error may vary by $9.8 \%$ more or less.

- Rio Grande do Sul: the planted area was estimated based on information provided by individual members to ABRAF and by direct contact with forestry companies not associated with ABRAF. It is estimated that the margin of error can vary by $16.4 \%$ more or less.

- Santa Catarina: the planted area was estimated from information provided by individual ABRAF members, by collective members of the Catarinense Association of Forestry Companies (ACR), APRE and AFUBRA, as well as by direct contact with forestry companies not associated with ABRAF. It is estimated that the margin of error can vary by $16.4 \%$ more or less.

- São Paulo: the planted area was estimated based on the information provided by ABRAF's individual members and by direct contact with nonABRAF forestry companies. It is estimated that the margin of error may vary by $10.1 \%$ more or less.

- Tocantins: the planted area was estimated based on information made available by individual members to ABRAF, by the Association of Tocantins Reforesters (ARETINS), and by direct contact with non-ABRAF forestry companies. It is estimated that the margin of error may vary by $9.8 \%$ more or less.

- Piaui: the planted area was estimated based on the information made available by ABRAF individual members and by direct contact with forestry companies not associated with ABRAF. It is estimated that the margin of error can vary by $8.2 \%$ more or less.

- Other states: the area planted in the other states was estimated through the compilation of information provided by individual members to ABRAF and direct contact with forestry companies not associated with ABRAF.

The error statistics were obtained through data variability, the greater the variability, the greater the statistical error (ABRAF, 2006 to 2013).

Inflation in the period 2006 to 2020 was assessed according to data from the Brazilian Institute of Geography and Statistics (IBGE) (IBGE, 2020).

The financial values of R\&D investments by forestry companies, Pinus and Eucalyptus wood prices were corrected / deflated for the year 2020. These values were updated / corrected using the IBGE historical series (IBGE, 2020), and their respective accumulated values in the period 2006 to 2020 (current). 
Inflation (\%) acu. $=\sum_{i=2006}^{2020} i_{2006}+i_{2007}+\cdots+i_{2020}[1]$ On what:

Inflation (\%) $)_{a c u}=$ accumulated inflation in the period 2006 to 2020 given in percentage.

$i_{n}=$ annual inflation observed as a percentage in Brazil in the umpteenth year.

\section{Calculations to Assess $R \& D$ Gains}

To assess the average productivity of wood in Brazil, the average for each Brazilian state of Eucalyptus and Pinus species was considered, weighted according to the planted plant areas, according to the weighting methodology proposed by Filho et al., (2019), and described in the equation below:

Pro $_{a v r .}\left(\frac{m^{3}}{-} h a-a n o\right)=\sum_{i=1}^{n} \frac{\omega_{a m} \chi_{a m}+\omega_{b a} \chi_{b a}+\cdots+\omega_{n} \chi_{n}}{\chi_{a m}+\chi_{b a}+\cdots+\chi_{n}}[2]$

On what:

Pro $o_{\text {avr. }}=$ average productivity weighted by planted area (ha).

$\omega_{n}=$ productivity of Pinus or Eucalyptus in the umpteenth state of Brazil.

$\chi_{n}=$ planted area of Pinus and Eucalyptus in the umpteenth Brazilian state.

The average price of Pinus and Eucalyptus wood was also calculated weighted by the area planted by each species in the territory of Brazil, according to the equation below:

$$
\begin{array}{r}
\operatorname{Pri}_{a v r .}\left(R \$ / m^{3}\right)= \\
\sum_{i=1}^{n} \frac{\rho_{a m} \chi_{a m}+\rho_{b a} \chi_{b a}+\cdots+\rho \chi_{n}}{\chi_{a m}+\chi_{b a}+\cdots+\chi_{n}}
\end{array}
$$

On what:

Pri $i_{\text {avr. }}=$ average price of wood weighted by planted area (ha).

$\rho_{n}=$ price of wood of Pinus or Eucalyptus in the umpteenth state of Brazil.

$\chi_{n}=$ planted area of Pinus and Eucalyptus in the umpteenth Brazilian state.

In order to obtain a clear cause-effect relationship between investment and revenue, the investments of the companies that were basically the companies associated with ABRAF and those described above in this article were counted, with the forest product considered by the companies basically wood, Pinus or Eucalyptus. In other words, of the 27 companies associated with ABRAF, only 1 has Tectona grandis wood as its main, which is responsible for only a small part of the investment between ABRAF member companies. However, the investments made by Floresteca were removed from the analysis to avoid confusion in the analysis of the data, which would not make sense. In this sense, the calculation of investments made by companies was carried out according to the equation below:

Inves.tot $_{\text {In }}(R \$)=\sum_{n=1}^{27} I_{1}+I_{2}+I_{3}+\cdots+I_{27}$ [4] On what:

Inves $_{\text {tot }}=$ total investment made by Brazilian forestry companies.
$I_{n}=$ investment made by the $\mathrm{n}$-th forestry company in Brazil.

After having all the data of average wood productivity organized on an annual basis, it was possible to calculate the gains obtained from year to another year (marginal gain), relative to the hectare, given according to the equation below:

$G_{\text {wood }}\left(m^{3} /\right.$ ha $/$ ano $)=\sum_{n=2006}^{2013}$ Pro $_{\text {avr. } n+1}-$ Pro $_{\text {avr. } n}$

On what:

$G_{\text {wood }}=$ marginal gain in wood productivity between 2006 to 2013.

Pro $_{\text {avr. } n}=$ average wood productivity in the nth year.

Consequently, the financial gains related to wood productivity gains in reais were calculated through the product between the annual marginal productivity gain and the market price of Pinus and Eucalyptus wood, according to the equation below:

On what:

$$
\begin{array}{r}
G_{\text {wood }}\left(m^{3}\right)= \\
\sum_{n=2006}^{2013} G_{\text {wood } n} \times \text { Pri }_{\text {avr. } n}
\end{array}
$$

$G_{\text {wood }}=$ financial gain obtained by investments in research from 2006 to 2013 in Brazil.

$G_{\text {wood }}=$ marginal gain in wood productivity in the nth year.

$P r i_{\text {avr. }}=$ average price of wood weighted by planted area (ha) in the nth year.

With this information, it was possible to establish an index of investment in $R \& D$ and economic return ( $\mathrm{I} / \mathrm{R}$ ), which in accounting is commonly called Return on Investment (ROI). The simplest expression of ROI, which is applied to information extracted from accounting, is given by the following equation:

On what:

$$
I / R=\sum_{n=2006}^{2013} \frac{I_{n}}{G_{\text {wood }}}
$$

$I / R$ = investment on return index.

$I_{n}=$ investment made by the $n$th forestry company in Brazil.

$R_{R \$}=$ financial gain obtained by investments in research from 2006 to 2013 in Brazil.

Pearson's product moment correlation coefficient was used for Box-Cox transformed data with statistical significance determined with the Student's t-test ( $p<0.05)$. Linear correlations were performed for the variables: average area planted (ha), Pro $_{\text {avr. }}\left(\mathrm{m}^{3} / \mathrm{ha} / \mathrm{ano}\right), \quad$ Pri $i_{\text {avr., }}$ Inves.tot.. The angular coefficients of the linear equations generated by Pearson's correlations were analyzed to statistically visualize the tendencies of increasing or decreasing each of these variables (THIBOS et al., 2002).

\section{Results and discussion}

It can be seen in Figure 1 clearly that the area planted with Eucalyptus (AE) undergoes an increase in the years evaluated, and the area planted with 
Pinus (AP) goes through the reverse process. This can be verified by the angular coefficient of the AP line that is positive (angular coefficient $=254,539 \mathrm{x}$ ), that is, the trend of increasing the planted area over the years in Brazil, and with AP, the trend is negative $(-32,706 \mathrm{x})$. One of the explanations of the managers of the political bodies linked to the forestry area for this fact is that it is due to the change in the direction of the products to the pulp market with only Eucalyptus wood, and the unsuitability of Pinus wood for pulp production; as well as the production of energy through charcoal (ABRAF, 2014), which the Pinus wood is not suitable for this purpose.

Above all, it is clear that the total forest area planted in Brazil with vaious species increases every year, with the effective contribution of forests planted with Eucalyptus. The proportional contribution of timber supplied from natural forests has steadily declined to less than half of global demand in 2015, with current harvest rates for natural forests declining since 1995. This shift in dependence on forest plants to supply demand for forest products wood resulted from the increase in the area dedicated to planted forests $(50 \%$ increase between 1990 and 2015; Payn et al., 2015) combined with accelerated growth rates. Planted forests represent about 7\% of all forests (Whiteman, 2014). The fastest growing and most intensively managed plantations are responsible for only 1.5\% (54 million ha) of the world's forests, but provide a third of the supply of non-firewood (INDUFOR, 2012).

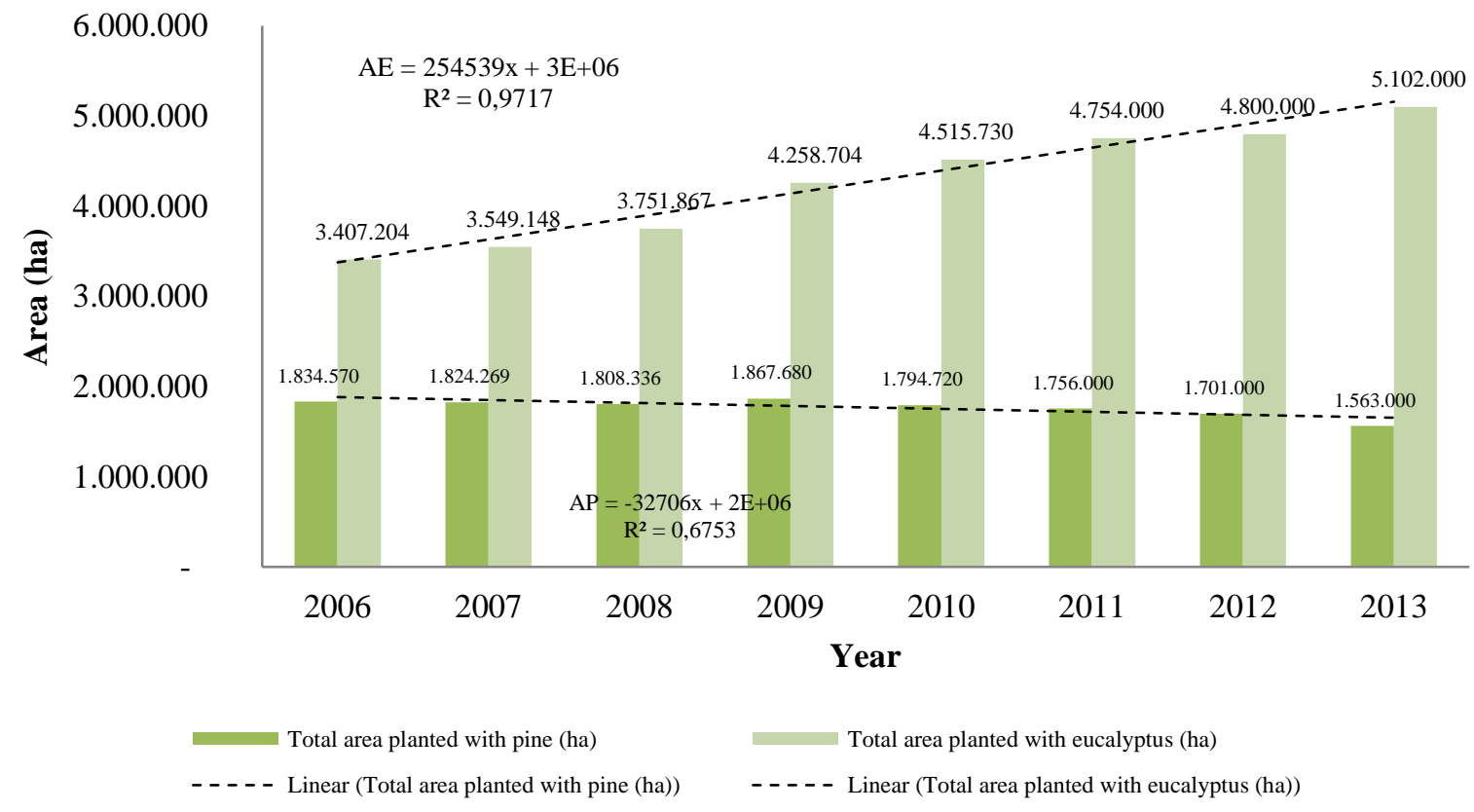

Figure 1. Area planted with Eucalyptus and Pinus in Brazil between the years 2006 and 2013. On what: AE = Eucalyptus planted area; AP = Pinus planted área

The rapid evolution of wood productivity obtained by Brazilian forestry companies between the years 2006 and 2013, from $30.9 \mathrm{~m}^{3}$ ha-1 year-1 in 2006, to more than $40 \mathrm{~m}^{3}$ ha-1 year-1 in 2013 (Figure 2). This increase in productivity can be associated with the reflexes of the most appropriate silvicultural practices associated with the increase in the level of improvement of genetic materials. The Average Annual Increment (IMA) of Eucalyptus in Brazil increased from about $10 \mathrm{~m}^{3}$ ha-1 year-1 obtained in the 70's to $41 \mathrm{~m}^{3}$ ha-1 year-1 in 2012 (ABRAF, 2013). From a silvicultural point of view, the implementation of minimum soil cultivation, the adequacy of fertilization programs and the effective control of weeds were the main management changes that occurred during the period (Gonçalves et al., 2008; Hakamada et al. 2015).

On the other hand, the gains in productivity have been smaller since 2009, with the absolute gains not exceeding $0.5 \mathrm{~m}^{3}$ ha- 1 year- 1 after 2009 (2012 to 2013), whereas before from 2009, gains of up to $3.4 \mathrm{~m}^{3}$ ha-1 year- 1 were obtained, which was the case for productivity from 2006 to 2007 (Figure 2). As the Eucalyptus crop has a long cycle compared to the cycle of other annual crops, it cannot be to state that the losses / gains in wood productivity in their respective harvest years occurred as a result of silvicultural management 
practices adopted in the same year in which the wood was harvested. According to Hakamada et al. (2015) silvicultural management has the function of increasing the availability of growth resources, such as water, light and nutrients (Nyland, 2007). Studies carried out with forest plantations that explored improvements in soil preparation practices (Nilsson; Allen, 2003), fertilization (Nilsson et al., 2002), spacing adjustment (Silva, 2006) and control of weeds (Little et al., 2003), showed an increase in the uniformity and productivity of wood when there was an increase in the availability of resources, as a result of less competition between individuals (Binkley et al., 2002), however this occurs throughout of a cycle of 5, 6, 7 years, or more, in the case of Pinus, which is the equivalent of a rotation in Brazil today. This was a methodological limitation of this work, since it is not identified exactly when the gain was realized, that is, it is not known throughout the cycle when the Technology was used, however it is intended here to demonstrate general trends of increase / decrease investments in $\mathrm{R} \& \mathrm{D}$ and their respective impacts on productivity, and not exactly measuring the annual gains in these indexes.

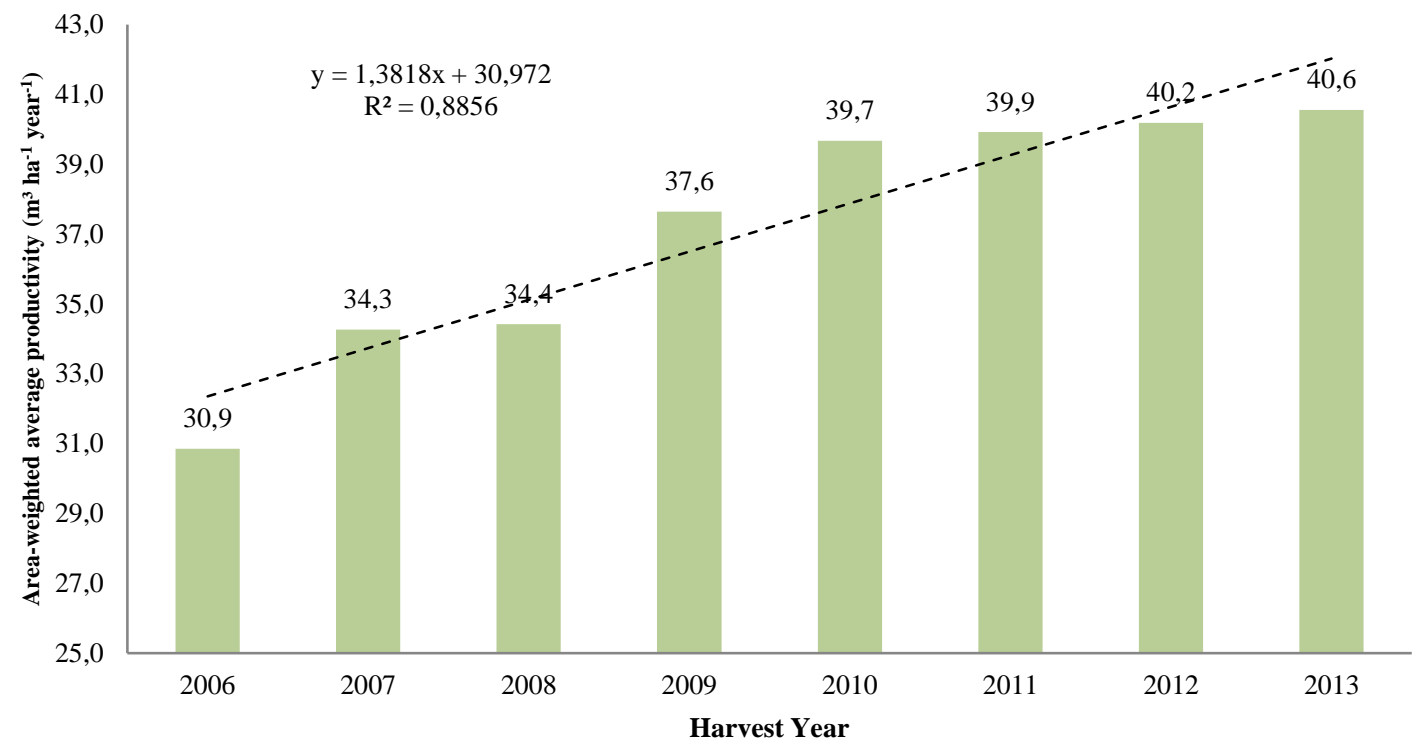

Figure 2 - average Pinus and Eucalyptus wood productivity weighted by planted area in Brazil between 2006 and 2013

Over the period 2006-2020, Brazilian inflation behaved in a heterogeneous manner in terms of the distribution of values over the period studied (Figure 3 ). This period was marked by high growth in international commodity prices, nominal exchange rate volatility and different phases of the influence of unit labor costs on the Brazilian inflationary process (Gomes and Freitas, 2020). From 2006 to 2014, the Brazilian inflation rate was average, varying from $3.1 \%$ to $6.4 \%$, in 2015 it was considered high $10.7 \%$, passing the double-digit barriers, and from 2016 to 2020, it returned to medium levels again. Additionally, the factors responsible for the inflationary dynamics were different throughout the decade, being: i) a phase of accelerated growth in the Brazilian economy (20062009), taking advantage of the favorable international scenario, both in terms of liquidity and in terms of growth rate of the world economy and international trade, ii) for a year of contraction in 2009 , as a result of the most accentuated moment of the Subprime crisis and that of 2008 (Maciel et al., 2012 ); iii) 2010 to 2014 due to a favorable external scenario after the Subprime crisis and the emergence of third world countries; iv) were marked by a period of stagnation (2015-2020) due to the Brazilian political crisis, which continues to the present day.

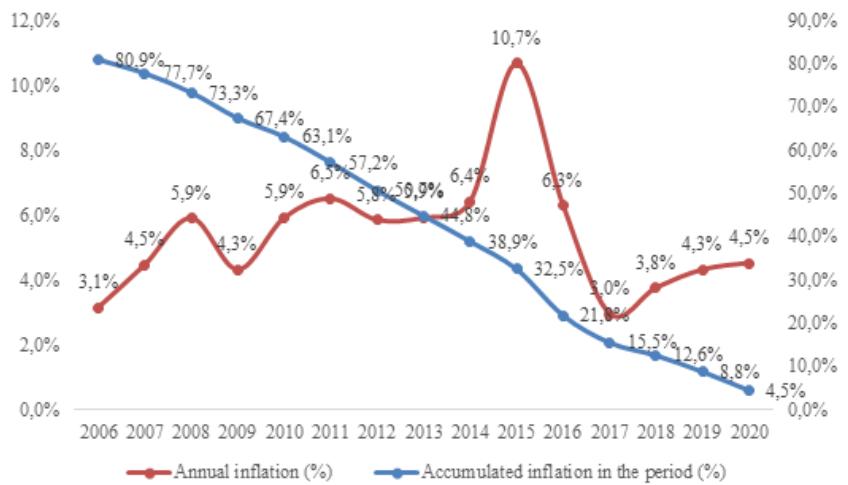

Figure 3 - Annual inflation observed in Brazil and its respective accumulations in the evaluated period of these studies. The values in parentheses correspond to the variant coefficients in percentage. 
Figure 4 shows the rapid devaluation of the average price of wood in Brazil in the period evaluated, a fact seen when analyzing the data angular coefficient of the line generated with the data $\left(\mathrm{R}^{2}=0.8318\right)$, and angular coefficient of -2.3058). According to Almeida et al. (2019) wood prices in Brazil, despite showing high and low movements over the years, have had constant decreases. The author also concludes that analyzing the historical series of the real price of Eucalyptus, even without inflation, we noticed that the value of the product decreased, while the prices of Pinus were more stable over the period. The volatility in wood prices, with frequent price reductions, were the result of high wood stocks and crises in the specific charcoal sector, which is totally linked to a crisis in the steel sector (Miranda et al., 2014).

Another point is the fact that inflation in the period 2006 to 2013 rises rapidly in Brazil, especially after the year 2008 (Figure 4). This shows a negative and unfavorable financial and economic scenario for wood producers, as it shows a scenario in that: i) company revenues fall due to the fall in wood prices, ii) production costs go up as demonstrated by the rise in inflation over the years, and automatically, iii) the profit margin is pressed down and the forestry business it becomes unattractive. Another fact that further aggravates the delicate situation of Brazil's wood producers is the issue that the inflation of forest production measured by the National Index of Costs of Forestry Activity (INCAF-Poyry) is generally above the average inflation in Brazil. For example, in 2012, inflation in the Brazilian forestry sector was $14.7 \%$ per year (p.y.), three times higher than the IPCA (5.8\% p.y.) and four times higher than the average international inflation (4.0\% p.y.) (ABRAF, 2013). This overheated inflation in the forestry sector be due to several factors, such as, for example, the increase in the prices of diesel oil and imported fertilizers, due to the appreciation of the international price of the barrel of oil and the dollar over the years of the evaluated period (Chernov and Sornette, 2020). In this sense, the increase in the exchange rate influences the increase not only of fertilizers and diesel oil, but also of several inputs used in the forest production area that are imported, such as insecticides, fungicides, herbicides, which are imported from several countries of the world.

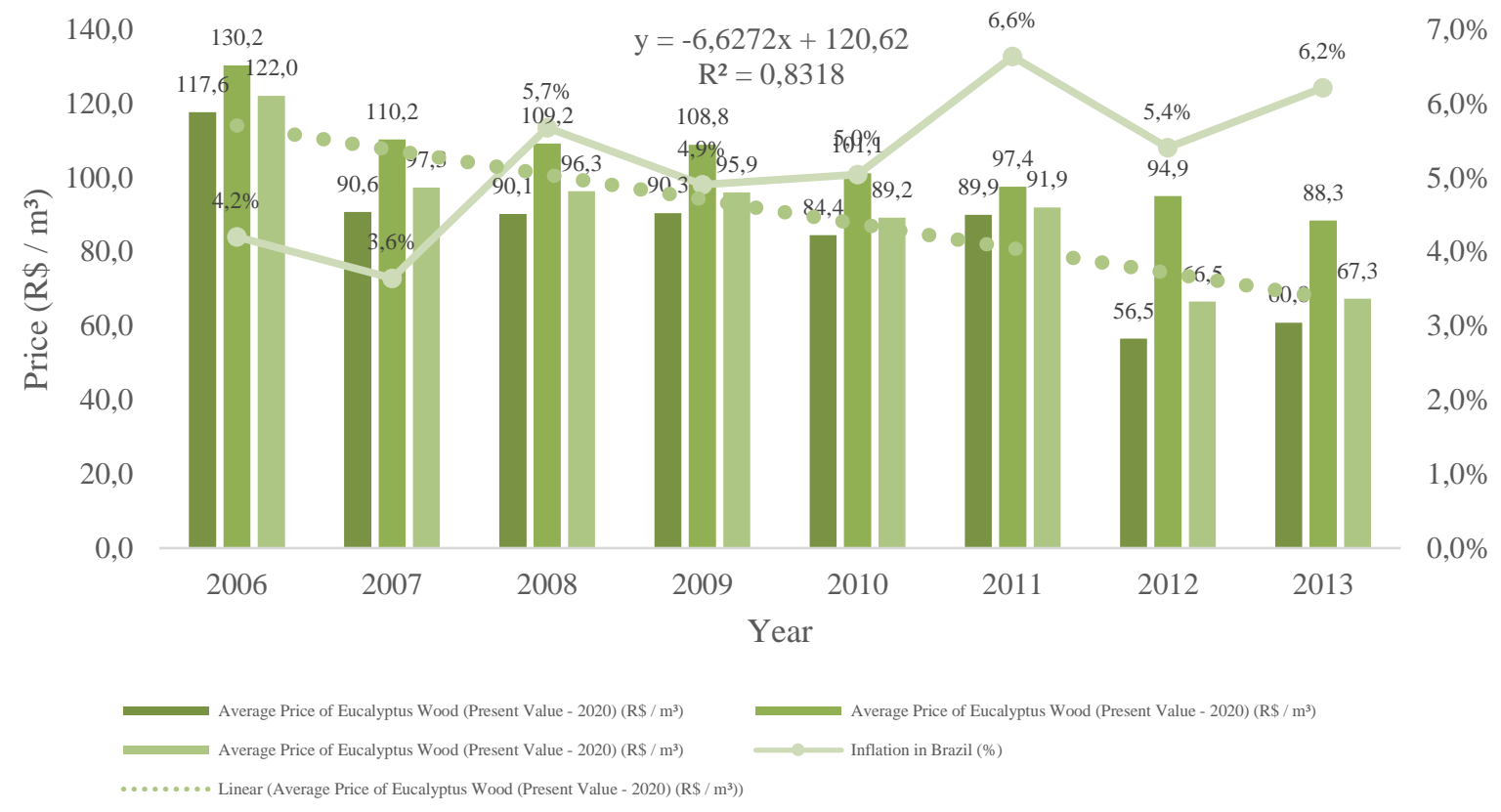

Figure 4 - Average price of Eucalyptus and Pinus wood from 2006 to 2013 in Brazilian forestry companies and inflation in the period in Brazil during the period evaluated.

Investments in R\&D made by Brazilian forestry sector decreased during the period evaluated, especially in 2009, as shown in Figure 5. This reduction in investments in $R \& D$ was due to the 2008 crisis, caused by the high real estate speculation in the United States of America (USA). According to Guttmann (2015) this crisis was chained by the high investment of the US government in war policies, as well as the weakening of the economy (trade balance imbalance), and consequently, and abrupt devaluation of properties in the USA.

In this context, in 2005 Law 11.196 / 05, which became known as "Lei do Bem", creates the granting of tax incentives to legal entities that carry out research and development of technological innovation (MCTIC, 2019), and this fact encouraged some companies to invest, mainly in the years 2006 
to 2008 , the pre-crisis period of 2008. In the case of the planted forest sector, this was an excellent trigger to perpetuate investments in $\mathrm{R} \& \mathrm{D}$, since of the large companies in the planted forest sector, already had an R\&D area before 2005. It should be noted here that this sector has a peculiarity regarding the temporal dynamics of research, for example, in the area of forest genetic improvement, that development of a clone of Eucalyptus lasts a day from 14 to 21 years to have a clone with proven productivity performance. In other words, the time needed to develop research in these areas is different from several other sectors of the economy, being the same in the long term, which requires strong and stable policies for the generation of research products for the planted forest sector.

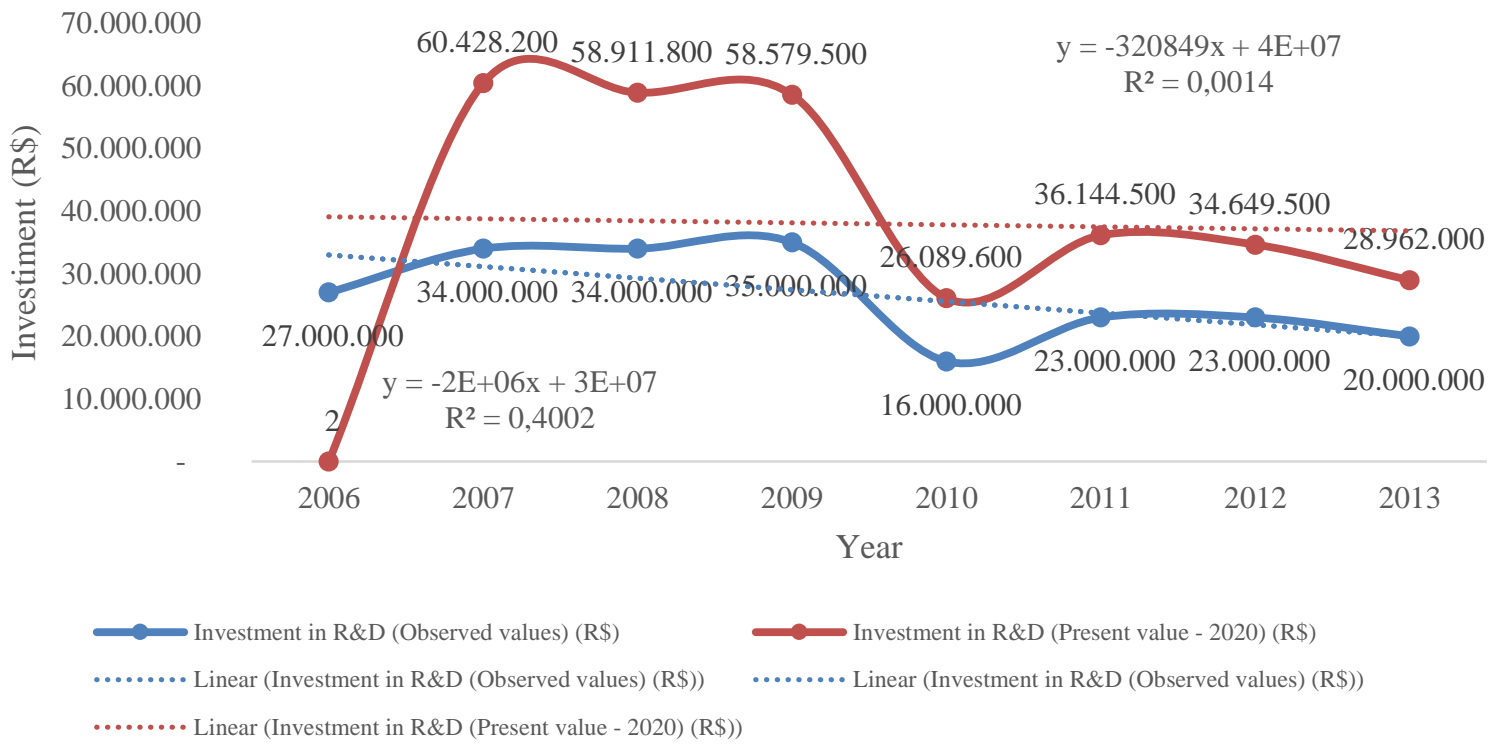

Figure 5 - Investment in R\&D in Brazilian forestry companies from 2006 to 2013.

Table 1 shows the high gross annual and total productivity gains, and the respective I / $\mathrm{R}$ ratios, showing how profitable the R\&D activity is for the brazilian forestry sector. In view of these results, it can be inferred that the average return for each $\mathrm{R} \$$ 1.00 invested in $\mathrm{R} \& \mathrm{D}$ results in an average return of $\mathrm{R} \$ 15.02(1,502 \%)$. However, it is clear that the indexes ranged from $\mathrm{R} \$ 1.28$ to $\mathrm{R} \$ 41.47$ annually, obviously due to variations in gains in annual productivity, also due to climatic variations, clones etc. Similar results were found by FIGUEIREDO (2008) in which, for each $\mathrm{R} \$ 1.00$ invested, the return was R\$ 13.67 for the orange crop in São Paulo. Other returns found by Araújo et al. (2002) for research in São Paulo agriculture and by Griliches (1975) for research in North American agriculture, of values between $\mathrm{R} \$ 10$ and $\mathrm{R} \$ 12$, and US\$13, respectively. Evenson, Pray and Rosegrant (1999) found values between US\$ 5 and US\$ 6 for agricultural research in India, values much lower than those estimated here. It is worth mentioning that these authors had data about investments in research in the private sector, in addition to considering the effects of irrigation, which was not possible to incorporate in the present study. Consider that some investments in forestry $R \& D$ have very different payback times from others, such as: i) investments in forestry improvement require between 14 to 21 years to record performance clone performance and

environmental adjustment; ii) investments in forest management experiments can take between 4 and 7 years to complete, for example, in relation to certain fertilizers with greater nutritional potential; iii) investments in operational development that take a few months to be concluded, for example on good mechanization practices and reduction of operating costs.

Making a comparative analysis in relation to the other types of low and high risk investments, it is clear that the average return on investment in R\&D projects $(1,502 \%)$ is much higher, such as, for example, those of IBOVESPA with an average annual return of $53.4 \%$ (p.y) (Santos et al., 2009); or even investments in fixed income with very low risk, but return only $6.5 \%$ (р.y.).

The variables in this study were correlated, and it was observed that marginal gains in wood productivity were positively correlated with investments in $R \& D(r=0.43)$. This is very important is shows numerically that the investments in $\mathrm{R} \& \mathrm{D}$ made by forestry companies are giving 
consistent productivity results for the sector and making Brazil more competitive in the international market.

It can be seen that over the period 2006 to 2013 the Brazilian forestry sector goes through a phase of intrinsic inflation in the sector above average inflation in Brazil, a systemic and gradual reduction in average wood prices and, therefore, a gradual and permanent reduction in profit margins of forest producers. On the other hand, there is the exporting industrial sector, which has a list of exporting companies associated with IBÁ and which is composed of a select list of 40 companies that operate in the foreign market and save exports of cellulose, paper, panels, sawn wood and floors laminates. The value exported by these companies in 2015 is approximately US\$ 9 billion (IBÁ, 2016). According to Hersen et al. (2019) an exchange rate policy with sharp devaluation, initiated in 2012, has resulted in additional gains for the exporting timber forestry sector, in special industrialized products. However, these benefits are concentrated in a small number of large companies, with the possibility of further improving the performance of the forestry industry made for small producers, through opportunities also, or micro and small companies using the international market. In this sense, an antagonistic relationship is perceived between the prices and results of forest-based companies and the prices practiced in the wood market, which is the medium and small producer of wood that is being used, being used by other alternatives to increase the added value of wood so that the forestry business returns to execute in terms of profitability.

\begin{tabular}{ccccc}
\hline Year & $\begin{array}{c}\text { Marginal } \\
\text { gains wood } \\
\left(\mathbf{m}^{3} / \mathrm{ha} / \text { ano) }\right.\end{array}$ & $\begin{array}{c}\text { Total wood } \\
\text { gain per year } \\
\text { in wood }\left(\mathbf{m}^{3}\right)\end{array}$ & $\begin{array}{c}\text { Marginal gains } \\
\text { (R\$) }\end{array}$ & Index (I/R) \\
\hline 2006 & - & - & - & - \\
2007 & 3,40 & 18.352 .503 & 1.785 .324 .233 & 26,99 \\
2008 & 0,20 & 872.813 & 84.051 .155 & 1,28 \\
2009 & 3,20 & 19.751 .888 & 1.895 .113 .018 & 30,45 \\
2010 & 2,00 & 12.801 .822 & 1.141 .414 .575 & 41,42 \\
2011 & 0,20 & 1.600 .271 & 147.085 .777 & 3,98 \\
2012 & 0,30 & 1.692 .289 & 112.613 .923 & 2,76 \\
2013 & 0,40 & 2.518 .958 & 169.456 .435 & 5,29 \\
\hline
\end{tabular}

On what: Index $(\mathrm{I} / \mathrm{R})=$ index that relates investments and revenues to $R \& D$ activities in forestry companies

\section{Conclusions}

In the period from 2006 to 2013 the Brazilian forestry sector goes through a phase of inflation intrinsic to the sector above the average inflation in Brazil, a systemic and gradual reduction in average wood prices and, therefore, a gradual and permanent reduction in the profit margins of forest producers.

Investments in R\&D projects carried out by Brazilian Eucalyptus and Pinus forestry promoted gains in wood productivity in the period from 2006 to 2013.

Forest R\&D is believed to be one of the most interesting business strategies for wood-producing companies to minimize the impacts of increased inflation, as well as the stable prices of commodities from forest products (cellulose, solid wood, briquettes, etc.) in national and international markets.

It can also be concluded with this work that investments in $\mathrm{R} \& \mathrm{D}$ projects translate economic returns for Brazilian forestry companies; on average, for each R\$ 1.00 invested, companies obtain an economic return of $\mathrm{R} \$ 15.02$.

\section{References}

ABRAF. Associação Brasileira de Produtores de Florestas Plantadas (2007) Anuário Estatístico da ABRAF: ano base 2006. Brasília.

ABRAF. Associação Brasileira de Produtores de Florestas Plantadas (2008) Anuário Estatístico da ABRAF: ano base 2007. Brasília

ABRAF. Associação Brasileira de Produtores de Florestas Plantadas (2009) Anuário Estatístico da ABRAF: ano base 2008. Brasília

ABRAF. Associação Brasileira de Produtores de Florestas Plantadas (2010) Anuário Estatístico da ABRAF: ano base 2009. Brasília.

ABRAF. Associação Brasileira de Produtores de Florestas Plantadas (2011) Anuário Estatístico da ABRAF: ano base 2010. Brasília

ABRAF. Associação Brasileira de Produtores de Florestas Plantadas (2012) Anuário Estatístico da ABRAF: ano base 2011. Brasília

ABRAF. Associação Brasileira de Produtores de Florestas Plantadas (2013) Anuário Estatístico da ABRAF: ano base 2012. Brasília

ABRAF. Associação Brasileira de Produtores de Florestas Plantadas (2014) Anuário Estatístico da ABRAF: ano base 2013. Brasília.

Almeida JS, Santos EKH, Borges FQ (2019) Dinâmica temporal dos preços de madeira serrada de Eucalyptus sp. no estado de São Paulo. Revista Observatorio de la Economía Latinoamericana, março 2019.

Alston JL, Craig BJ, Pardey PG (1998) Dynamics in the creation and depreciation of knowledge, and the 
returns to research. Washington: IFPRI, $51 \mathrm{p}$. (Discussion Paper, 35).

Araújo PFC, Schuh GE, Barros, ALMB, Shirota R, Nicolella, AC (2002) O crescimento da agricultura paulista e as instituições de ensino, pesquisa e extensão numa perspectiva de longo prazo. São Paulo: FAPESP, 172 p.

Ball, VE (2006) Productivity and output growth in US Agriculture. In: WIEBE, K.; GOLLEHON, N. (Editors). Agricultural Resources and Environmental Indicators Washington: Economic Research Service/USDA, chapter 3.4.

Binkley D, Stape JL, Ryan MG, Barnard H, Fownes J (2002) Age-related decline in forest ecosystem growth: an individual-tree stand-structure hypothesis. Ecosystems, New York, 5(1):58- 67.

Chernov D., Sornette D. (2020) Specific Features of Risk Management in the Industrial and Agricultural Sectors. In: Critical Risks of Different Economic Sectors. Springer, Cham

Evenson RE, Pray CE, Rosegrant MW (1999) Agricultural research and productivity in India. Washington: IFPRI, p. 213, (Research Report, 109).

Figueiredo MG (2008) Retorno Econômico dos Investimentos em Pesquisa e Desenvolvimento (P\&D) na Citricultura Paulista. Thesis, Escola Superior de Agricultura "Luiz de Queiroz", Universidade de São Paulo.

Filho CGC, Viegas TOC, Carvalho VS (2019) The behavior of total factor productivity and the decomposition of growth for the Brazilian economy between 1955-2009. Brazilian Applied Science Review, 3(6): not paginated. https://doi.org/10.1186/s40008-018-0122-2

Fuglie K, Ballenger N, Day K, Klotz C, Ollinger M, Reilly J, Vasavada U, Yee J (1996) Agricultural research and development: public and private investments under alternative markets and institutions. Washington: USDA, Economic Research Service - ERS, 88 p. (Agricultural Economics Report, 735).

Garcia-Marin A, Voigtländer N (2019) "Exporting and Plant-Level Efficiency Gains: It's in the Measure," Journal of Political Economy 127(4): 1777-1825. https://doi.org/10.1086/701607

Gasques, JG, Conceição JCPR (2000) Transformações estruturais da agricultura e produtividade total dos fatores. Brasília: IPEA, $62 \mathrm{p}$. (Text for discussion, 768).
Gomes L, Freitas F (2020) A dinâmica inflacionária no Brasil de 2000 a 2009: uma abordagem multissetorial. Economia e Sociedade, 29(1):327357.

Gonçalves JLM, Stape JL, Laclau J-P, Bouillet, J-P, Ranger J (2008) Assessing the effects of early silvicultural management on long-term site productivity of fast-growing eucalypt plantations: the Brazilian experience. Southern Forests: a Journal of Forest Science, 70(2):105-118.

Griliches Z (1975) Despesas em pesquisa e educação na função de produção agrícola agregada. In: ARAÚJO PFC, Schuh GE Desenvolvimento da agricultura. São Paulo: Pioneira, cap. 2, p. 101-116.

Guttmann R (2015). Chronic macro-economic and financial imbalances in the world economy: a metaeconomic view. Brazilian Journal of Political Economy, 35(2):289-298. https://doi.org/10.1590/0101-31572015v35n02a01.

Hakamada RE, Stape JL, Lemos CCZ, Almeida AA, Silva LF (2015) Uso do inventário florestal e da uniformidade entre árvores como ferramenta de monitoramento da qualidade silvicultural em plantios clonais de eucalipto. Scientia Forestalis, 43(105):27-36.

Hersen A, Hoeflich VA, Lima JF (2019) A desvalorização cambial e a exportação de produtos florestais madeireiros. Revista de Economia e Sociologia Rural, 57(3):368-378. https://doi.org/10.1590/1806-9479.2019.186857

Huffman WE, Evenson RE(1993) Science for agriculture. Ames: Iowa State Univesity Press, 314p.

Indufor (2012) Strategic review on the future of forest plantations, report prepared for the Forest Stewardship Council. Helsinki: INDUFOR (A1206869 ID 11914), $11 \mathrm{p}$.

IBA. Brazilian Tree Industry (2015) Brazilian Tree Industry Annual Report. Brasília: IBA, 80p.

IBGE. INSTITUTO BRASILEIRO DE GEOGRAFIA E ESTATÍSTICA (2019). Brasília: IBGE, not paginated.

Lee J (2020) How to Establish Industrial AI Technology and Capability. In: Industrial AI. Springer, Singapore.

Little KM, van Staden J, Clarke GPY (2003) Eucalyptus grandis x E. camaldulensis variability and intra-genotypic competition as a function of different vegetation management treatments. New Forests, 25(3):227-242. 
MACIEL L, SILVEIRA R L F, LUNA I, BALLINI $R$ (2012) Impacto dos contratos futuros do Ibovespa na volatilidade dos índices de ações no Brasil: uma análise na crise do subprime. Estud. Econ., 42 (4):801-825. http://dx.doi.org/10.1590/S010141612012000400006 .

MCTIC. MINISTÉRIO DA CIÊNCIA, TECNOLOGIA, INOVAÇOES E COMUNICAÇÕES (2019). 1st Edition. Guia Prático da Lei do Bem, Brasília: MCTIC, 80p.

Miranda M, Leite C, Valverde S, Silva M (2014). Análise da rentabilidade de um projeto florestal considerando variação anual no preço do carvão vegetal. Revista Agrogeoambiental, 6(3):not paginated. doi:http://dx.doi.org/10.18406/23161817 v6n32014679

Nilsson U, Albaugh T, Allen HL (2002) Development of size hierarchies prior to the onset of density-dependent mortality in irrigated and fertilized loblolly Pinus stands. Canadian Journal of Forest Research, 32(6):989-996.

Nilsson U, Allen HL (2003) Short- and long-term effects of site preparation, fertilization and vegetation control on growth and stand development of planted loblolly Pinus. Forest Ecology and Management, 175(1-3):367-377.

Nyland RD (2007) Silviculture: concepts and applications. 2nd Edition. Long Grove: Waveland press, $682 \mathrm{p}$.

Rosegrant MW, Evenson RE (1992) Agricultural productivity and sources of growth in South Asia. American Journal of Agricultural Economics, 74(3):757-761.

Payn T, Carnus J-M, Freer-Smith P, Kimberley M, Kollert W, Liu S, Orazio C, Rodriguez L, Silva LN, Wingfield MJ (2015) Changes in planted forests and future global implications. Forest Ecology and Management., 352(57):50-67.

Santos JO, Coelho PA (2010) Análise da relação risco e retorno em carteiras compostas por índices de bolsa de valores de países desenvolvidos e de países emergentes integrantes do bloco econômico BRIC. Revista contabilidade e finanças, 21(54): non page http://dx.doi.org/10.1590/S151970772010000300003.

Silva CR (2006) Efeito do espaçamento e do arranjo de plantio na produtividade e uniformidade de clones de Eucalyptus na região Nordeste do Estado de São Paulo. Dissertation Escola Superior de Agricultura "Luiz de Queiroz", Universidade de São Paulo. 202p.

Ruttan VW (1982) Agricultural research policy. Minneapolis: University of Minnesota, Not paginated. Mimeographed.

Thibos LN, Hong X, Bradley A, Cheng X (2002). Statistical variation of aberration structure and image quality in a normal population of healthy eyes. Journal of the Optical Society of America A, Optics, Image Science, and Vision, 19(1):2329-2348.

Yee J, Huffman WE, Ahearn M, Newton D (2002) Sources of agricultural productivity growth at the state level, 1960-1993. In: BALL, V.E.; NORTON, G.W. (ed). Agricultural productivity: measurement and sources of growth. Norwell: Kluwer, 2002. p. 184-212.

Wen GJ (!993) Total factor productivity in China's farming sector: 1952-1989. Economic Development and Cultural Change, 42(1):not paginated.

Whiteman A (2014) Global trends and outlook for forest resources. In: Fenning T (ed) Challenges and opportunities for the world's forests in the 21st century. New York: Springer, 151-182p. 10.1007/978-94-007-7076-8_8.. 